\title{
Performing coronary artery bypass grafting with a giant left internal mammary artery; Using dilated internal mammary artery in a patient with aortic coarctation and concomitant coronary artery disease
}

\section{Dev bir sol internal mammaryen ile koroner arter bypass greftleme; Eş zamanlı aort koarktasyonu ve koroner arter hastalığı olan hastada dilate internal mammaryen arter kullanımı}

\author{
Eren Gunertem ${ }^{1 *}$ (D) Gokhan Lafci ${ }^{2}$ (D) \\ ${ }^{1}$ University of Health Sciences, Numune Training and Research Hospital, Department of Cardiovascular Surgery, Ankara, Turkey \\ ${ }^{2}$ University of Health Sciences, Turkiye Yuksek Ihtisas Training and Research Hospital, Department of Cardiovascular Surgery, Ankara, \\ Turkey \\ * Corresponding author: Eren Gunertem E-mail: egunertem@yahoo.com.tr ORCID: 0000-0002-7132-8586 \\ Received: 16 Ekim 2018 Accepted: 14 May 2019
}

\begin{abstract}
The ideal surgical approach is unclear for patients with aortic coarctation whom have other associated coronary artery disease or other cardiac pathologies. A 69 year-old male was admitted to our hospital with carotid artery stenosis and coronary artery disease. During routine preoperative procedures cardiologist revealed an aortic coarctation. Left internal mammary artery was dilated due to coarctation but even so it was used as a graft for coronary artery bypass grafting. We aimed to report our approach for this patient.
\end{abstract}

Keywords: aortic coarctation, internal mammary artery, coronary artery disease

\section{öz}

Eş zamanlı aort koarktasyonu ile koroner arter hastalığı gibi diğer kardiyak patolojileri olan hastalarda ideal tedavi yaklaşımı konusunda fikir birliği bulunmamaktadır. 69 yaşında erkek hasta hastanemize karotid arter darlığı ve koroner arter hastalığı tanılarıyla başvurdu. Ameliyat öncesi hazırlıklar sırasında hastada aynı zamanda aort koarktasyonu olduğu saptandı. Sol internal mammaryen arter dilateydi ancak yine de koroner arter bypass greftleme operasyonu sırasında greft olarak kullanıldı. Biz bu hastadaki yaklaşımımızı sunmak istedik.

Anahtar kelimeler: aort koarktasyonu, internal mammaryen arter, koroner arter hastalığı 


\section{CASE}

A 69 year-old male was admitted to our hospital with a syncope history. A doppler ultrasonography revealed a severe (\%90) carotid artery stenosis and diagnose confirmed with digital subtraction angiography. His medical history included hypertension, diabetes and hyperlipidemia. On admission our patient's left ventricular ejection fraction was $\% 50$ without any valvular disease. His EuroScore II was calculated \%5.04. A coronary angiography via femoral artery was performed under suspicious of coronary artery disease. During procedure cardiologist revealed an aortic coartation. A computed-tomography scan confirmed the diagnose and determined bilateral internal mammary artery dilatation (Figure 1). Then coronary angiography was repeated via radial artery and showed a \%90 osteal stenosis on left anterior descending artery which was not suitable for percutaneous coronary interventions. In the lights of these findings, coronary artery bypass grafting was planned in first place considering the severity of left anterior descending artery lesion. Localization of aortic coarctation was not suitable for posterior pericardial approach through median

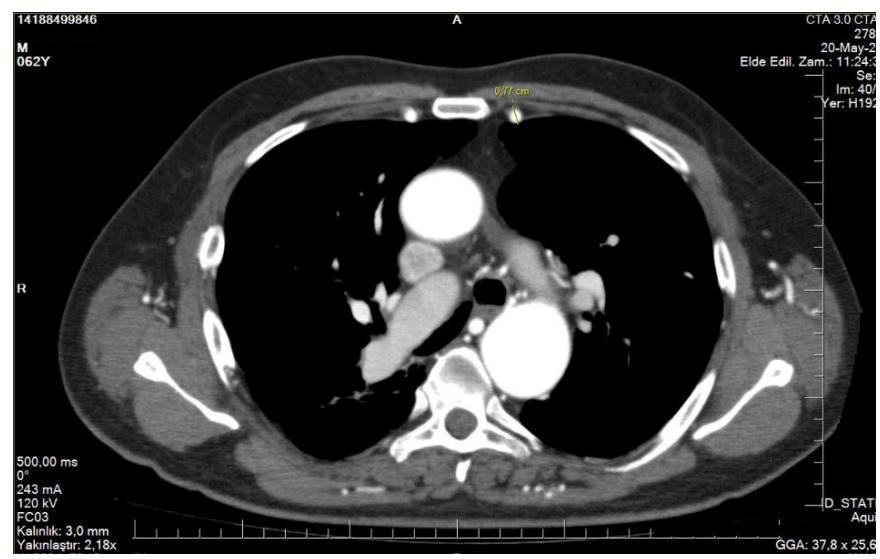

Figure 1. Dilated left internal mammary artery was seen in computed-tomography scan

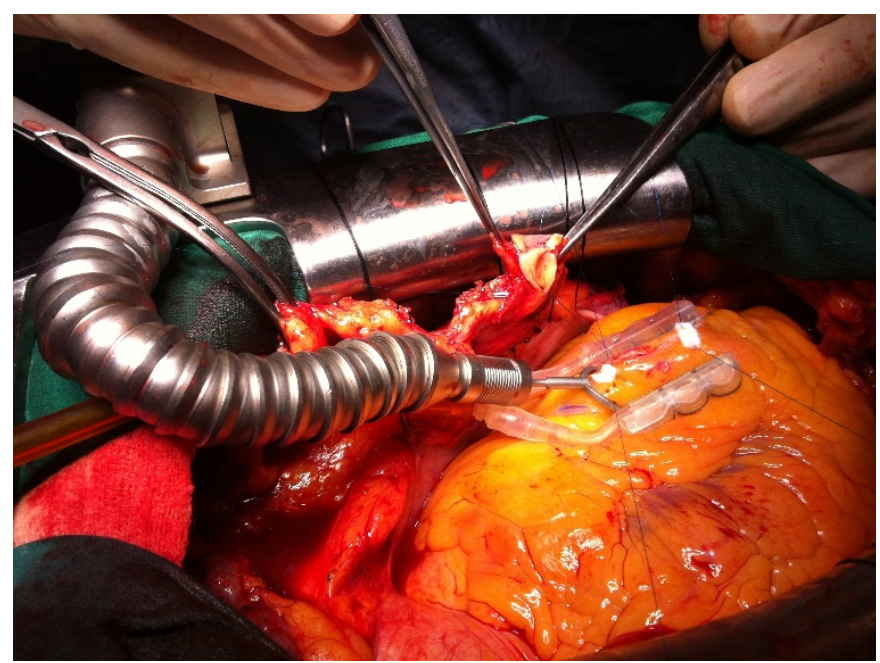

Figure 2. Intraoperative image: Coronary artery bypass grafting with dilated left internal mammary artery sternotomy. For this reason we planned to repair the aortic coarctation later with a thoracotomy. Then patient was undergo surgery. After median sternotomy a large internal mammary artery was observed. It was found to be pliable and free of calcification, although massively dilated and tortuous. It had a tremendous flow. Other collateral circulations to lower extremity was enough as we have seen in computed-tomography scan. We thought that it was suitable for use as a conduit for revascularization. We did not have any suitable device for flow measurement that's why we could not have perform. Coronary artery bypass grafting was performed with this graft to the left anterior descending artery (Figure 2). In same session carotid endarterectomy was made. 5 days after surgery patient was discharged. 45 days after surgery, our patients came to our clinic for routine postoperative control. He was semptom-free and his physical examination was totally normal. There aren't any findings which can show us a distal malperfusion due to using left internal mammary artery. We have planned to repair the aortic coarctation one month later. But unfortunately, our patient did not come yet to our hospital for surgery.

\section{DISCUSSION}

Although coarctation of the aorta is a congenital defect, it could be diagnosed in adulthood because patients can remain asymptomatic for many years. Especially in adult patients, extensive collateral circulation between proximal to distal part of coarctation is one of the striking features of this condition. Sources are mainly both subclavian arteries, particularly the internal thoracic and vertebral arteries [1]. Atipo-Galloye and his colleagues showed a dilated left internal mammarian artery in a 19 year-old woman with aortic coartation [2]. In adult patients with aortic coarctation in combination with other cardiovascular diseases, there is no consensus on the optimal treatment approach. Some authors have suggested a single-stage repair [3-4]. In our patient we decided to repair aortic coarctation in another surgical session due to priority of coronary artery disease and symptomatic carotid artery stenosis. Furthermore, localization of coarctation was not suitable for posterior pericardial approach through median sternotomy. The left internal mammary artery to the left anterior descending artery is recognized as the gold standard for revascularization. Several studies have shown the benefits of the left internal mammary artery [5]. The choice of conduits for surgical revascularization in patients with aortic coarctation can be engrossing. Internal mammary artery can be dilated, atherosclerotic and unsuitable for grafting. Reports in the literature are controversial: in some cases, the 
internal mammary artery was not suitable for revascularization, while in others, it could be used with good outcomes [6]. For this reason, we used left anterior descending artery for revascularization which was seen suitable for use even if it was dilated.

\section{CONCLUSION}

Aortic coartation is a congenital disease it can also exist in adult patients rarely and combine with other cardiac disease. In our patient diagnose was established incidentally during a coronary angiography. There are a lot of treatment option for this condition. We believe that this case report of a rare condition can help cardiovascular surgeons when they face with a similar situation.

\section{DECLARATION OF CONFLICT OF INTEREST}

The authors received no financial support for the research and/or authorship of this article. There is no conflict of interest.

\section{REFERENCES}

1. Laks H, Marelli D, Plunkett M, Odim J, Myers J. Adult congenital heart disease. In Cardiac Surgery in the adult. 2nd edition. Edited by Lawrence $\mathrm{H}$ Cohn and L. Henry Edmunds Jr. New York, McGraw - Hill; 2003: 1329-58.
2. Atipo-Galloye R, Rhissassi J, Koulekey C. Dilatation of internal mammary arteries in adult presenting aortic coarctation. Asian Cardiovasc Thorac Ann 2014; 22: 365.

3. Alvarez JR, Lopez LR, Quiroga JS, Martinez Comendador JM, Martinez-de-Alegria A, Martinez Cereijo JM, Dominguez CD. Internal mammary artery dilatation in a patient with aortic coarctation, aortic stenosis, and coronary disease. Case report. J Cardiothorac Surg 2011; 6: 55.

4. Yilmaz M, Polat B, Saba D. Single-stage repair of adult aortic coarctation and concomitant cardiovascular pathologies: a new alternative surgical approach. J Cardiothorac Surg 2006; 1: 18.

5. Goldman S, Zadina K, Moritz T, Ovitt T, Sethi G, Copeland JG, Thottapurathu L, Krasnicka B, Ellis N, Anderson RJ, Henderson W. Long-term patency of saphenous vein and left internal mammary artery grafts after coronary artery bypass surgery: results from a Department of Veterans Affairs Cooperative Study. J Am Coll Cardiol 2004; 44: 2149-56.

6. Mario Gaudino, Piero Farina, Amelia Toesca, Giorgia Bonalumi, Vasileios Tsiopoulos, Piergiorgio Bruno and Massimo Massetti: The use of internal thoracic artery grafts in patients with aortic coarctation. Eur J Cardiothorac Surg 2013; 44: 415-18. 